University of Nebraska - Lincoln

DigitalCommons@University of Nebraska - Lincoln

20th \& 21st Century French and Francophone Modern Languages and Literatures, Department Studies International Colloquium

\title{
The Returns of the Roman de la Terre : Défricheurs and their Migrant Others in the Canadien Imaginary
}

\author{
Alvin Y. Chuan \\ University of Southern California, achuan@usc.edu
}

Follow this and additional works at: https://digitalcommons.unl.edu/ffsc2020

Part of the Comparative Literature Commons, French and Francophone Literature Commons, and the Other French and Francophone Language and Literature Commons

Chuan, Alvin Y., "The Returns of the Roman de la Terre : Défricheurs and their Migrant Others in the Canadien Imaginary" (2020). 20th \& 21st Century French and Francophone Studies International Colloquium. 6.

https://digitalcommons.unl.edu/ffsc2020/6

This Article is brought to you for free and open access by the Modern Languages and Literatures, Department of at DigitalCommons@University of Nebraska - Lincoln. It has been accepted for inclusion in 20th \& 21st Century French and Francophone Studies International Colloquium by an authorized administrator of DigitalCommons@University of Nebraska - Lincoln. 


\section{The Returns of the Roman de la Terre : Défricheurs and their Migrant Others in the Canadien Imaginary}

\section{Alvin Y. CHUAN University of Southern California}

The theme "parler la terre" presents an opportunity to reconsider Québec's romans de la terre - farm novels from the turn of the Nineteenth Century into the Twentieth that are often considered to be the inaugural works of the province's literary canon. Variously known as the "roman du territoire" or the "roman paysan", this genre, with its idealized depictions of colonization and rural life, helped articulate what literary historian Dorothee Scholl would call the mythe du terroir - or in her own words, "the mythologizing of the soil as the site of FrenchCanadian national identity (103).” At the height of their popularity, these novels were heavily patronized by Catholic clergy, provincial politicians, and nationalist literary circles, who promoted the productions in order to discourage the rural flight of francophone Canadiens, 1 encouraging them to instead migrate internally and agriculturally exploit the Laurentians region north of Montréal. There is now a vast body of critique that examines how the agriculturalist ideology expressed through these farm novels helped reify notions of Franco-Canadian identity and territoriality. Transcending these studies, critics have also begun to read romans de la terre against the grain, highlighting the multi-dimensionality of the discourses of land in this genre. Some critics even diverge from the agriculturalist debate all together-for example, Sudarsan

\footnotetext{
1 During this era of colonization, the descendants of French settlers in Canada referred to themselves as "Canadiens"; Louis Hémon offers this sociological blurb in his 1913 novel, Maria Chapdelaine [the object of this article], "lorsque les Canadiens français parlent d'eux-mêmes, ils disent toujours « Canadiens », sans plus... C'est là un titre qu'ils se réservent tout naturellement et sans intention d'offense, de par leur héroïque antériorité (60)." Noting that in common usage "Canadien" now no longer carries the same connotation, and that "Canadien français" can even be considered pejorative - with francophones from Québec in particular preferring the demonym “Québécois" since the 1960s' Quiet Revolution - this article will respect the historical usage of these terms as they are used in the primary sources; because the novel refers to "Canadiens" and "Canadiens français," my analysis interrogates notions of Canadien and Franco-Canadien identity and territoriality, though not without opening questions on its impact on contemporary conceptions of Québecois identity.
} 
Rangarajan who does so in order to draw links between the roman de la terre and the contemporaneous French roman d'aventures (767). My paper, however, maintains that there remains work to be done in complicating the novels' agriculturalist fixation on land, in particular by reckoning with the settler-colonialist implications of this discourse. Before me, geographer Caroline Desbiens productively proposed that certain romans de la terre may be emphasized as romans de ressources - and rightfully so, as many of them do extol the extraction and economic mobilization of natural resources from newly colonized land (121). However, remarking that this exploitation is mediated by the movement of colonists across the national terroir, the question I raise instead is how romans de la terre may also be read as economic récits de la migration. Doing so will allow us to comprehend the place of human migration in the settler-colonialist imaginaries that informed Canadiens of their relationship with the land in the past, and perhaps even continue to shape Québécois territoriality in the present day.

As a case study, I turn to the emblematic roman de la terre, Louis Hémon's Maria Chapdelaine; understanding migration loosely as the displacement of humans across geographical space, I will demonstrate this 1913 novel to be a veritable reservoir of economic discourses of migration. Arguably a migrant novel avant la lettre,2 as Hémon (1880-1913) was a French immigrant to Canada, Maria Chapdelaine was inspired by its author's stay among Canadien colonists in the Lac-St-Jean region; published posthumously after the writer's tragic death by train, the first edition of this novel was, according to Hémon scholar Nicole Deschamps, heavily censured from being a "conte de neige et d'absence" into an "allégorie triomphaliste" (vii). In effect, working with Hémon's unabridged edition, literary critic Rosemary Chapman

2 "Migrant" is predominantly used in Québec literary studies to refer to immigrant writing emerging from the 1960s onwards. For this reason, Louis Hémon is not usually included in this corpus. For an overview on Canadian "migrant literature" see the introduction of critics Marie Carrière and Catherine's edited book, Migrance comparée/comparing Migration (6)." 
troubles the bucolic vision normally associated with Maria Chapdelaine, asserting that therein, "rather than amounting to a simple hymn to the agriculturalist way of life, the perspective on rural Quebec is made more complex because of the interplay of protagonists, with their conflicting responses to the Lac-Saint-Jean (81).” Just like their relationship with the territory, I show that the colonists' relationship with migration in the text are equally as complex, but nonetheless conditional to a sort of settler-colonialist system of values. Reflecting Maria Chapdelaine's popularity as the province's elite enforced their politiques de la colonization (Hamelin 415), the novel valorizes migrations that result in the settlement of the province's territory, while other forms of migrant mobility are distinguished and demonized. This colonialist conception of migrancies can be demonstrated by the eponymous Maria's three love interests who, I argue, each represent a distinct migrant type in the Canadien colonialist imaginary: the défricheur, the coureur des bois, and the citadin. Effectively, they are more than symbols of, in the words of literary critic Florian Freitag, "place-based identities whose mere geographical location is all that is necessary to identify their stance on the French Canadian [agriculturalist] cause (170);" their stances in the agriculturalist debate can be nuanced by the particular migrant and economic modalities that each figure practices.

The most celebrated figure in the novel is perhaps the défricheur-the agricultural laborer who acts as the agent of colonization in the field, converting woodland into arable land for potential settlers. This colonial type is reminiscent of Albert Memmi's quintessential portrait of the assiduous colonizer who leans on his shovel, gazing towards the periphery of his land as he tames nature and spreads culture (29).3 In the Québec context, a similar colonialist dimension taille, bronzé par le soleil, chaussé de demi-bottes, appuyé sur une pelle—car il ne dédaigne pas de mettre la main à l'ouvrage, fixant son regard au loin sur l'horizon de ses terres; entre deux actions contre la nature, il se prodigue aux 
characterized the défricheur, a notion that is evident in the very terminology these laborers affix to their work-faire de la terre, or as the novel's narrator explains, "la forte expression du pays, qui exprime tout ce qui gît de travail terrible entre la pauvreté du bois et la fertilité finale des champs labourés et semés (27)." In Maria Chapdelaine it is all but suggested that the importance of these pioneers lies in their so-called creation of land for imperial appropriation and subsequent exploitation. This centrality of the défricheurs' labor is demonstrated by the constant praise they attract in the novel; take for example this description of Mother Chapdelaine, who daydreams about the labor of the males in her family: “quand l'idée du coin de terre déblayé, magnifiquement nu, enfin prêt pour la culture, eut pénétré son esprit, elle montra une sorte d'extase mystique (48)."

The défricheurs' position as the ideal colonialist archetype is emphasized by both its migrant tendencies and also by its economic potentiality. Indeed, as much as they are agriculturalist icons, throughout Hémon's novel, the défricheurs are depicted to be migrant and economic types as well, as these settlers penetrate deeper and deeper into the woods, expanding the range of Canadien settlement and agricultural production. The migrancy of these défricheurs can be deduced from this passage in which Mother Chapdelaine laments, “c'est peut-être péché de le dire ; mais tout mon règne, j'aurai du regret que ton père ait eu le goût de mouver si souvent et de pousser plus loin et toujours plus loin dans le bois, au lieu de prendre une terre dans une des vieilles paroisses (20)." The sinfulness of her comment may very well be due to its criticism of the human movement necessary to colonize new land - to enter the woods and transform them into productive arable land. Whatever the case, Mother Chapdelaine's commentary gestures towards an interesting tension that characterizes the migrancy of 
défricheurs: while migration is needed to clear land for new settlements, incessant défrichement results in a certain instability due to its endless movement deeper and deeper into the woods. The migrant implications of défrichement thus show this practice to be steeped in two oppositional forces that may very well be a manifestation of that eternal tension between roots and mobility within the logic of settler-colonialism in Québec —-though the nation's territory is undeniably the fruit of mobile colonizers, in the end of the day it requires the finality of the Canadien rural migrant's rooting on settled land.

The novel seals this colonialist preference for this constrained mobility through Maria's decision to wed Eutrope Gagnon, a character who is also a défricheur and represents for the protagonist, "la vie d'à présent, dans une autre maison de bois, sur une autre terre mi-défrichée (149)." This choice of husband ultimately symbolizes Maria's choice to remain one of these migrant agricultural workers in the remote areas of Québec, and to subscribe to their mission of navigating the national terroir, both producing it and producing from it. To justify the viability of this lifestyle, Eutrope appeals to Maria,

je ne suis pas riche, bien sûr; mais j'ai deux lots à moi, tout payés, et vous savez que c'est de la bonne terre. Je vais travailler dessus tout le printemps... Je sèmerai cent trente minots...l'hiver d'après je monterai aux chantiers avec un cheval et je reviendrai au printemps avec pas moins de deux cents piastres dans ma poche, claires (149).

The constraint of his migration is rendered as his final stasis on newly cleared land, which in the end signifies the défricheur's profitability. The precariousness of the défricheur's migrant lifestyle is therefore offset by utopic images of potential wealth that may be extracted from the land in which he settles. It is in this way the migrant initiative of colonization is supported by an 
economic discourse that idealizes not only the initial movement into a piece of land, but also the ability to remain in it and, from it, turn a profit.

On the other hand, unconstrained movement that does not result in one's anchoring to the land is described by the novel as a sort of tragic idealism; exemplifying this is the figure of the coureur des bois, the iconic Franco-Canadian woodsmen from the days of New France who made their living from hunting, trapping, and guiding. This migrant type is represented by Maria's initial choice of lover, François Paradis, whose activities in the novel recall images of those woodsmen; for example, take this passage in which he explains to the Chapdelaines both his passion for wandering the land, as well as his objection to working on his family's farm, J'ai tout vendu. Je n'ai jamais été bien bon de la terre, vous savez. Travailler dans les chantiers, faire la chasse, gagner un peu d'argent de temps en temps à servir de guide ou à commercer avec les sauvages, ça c'est mon plaisir mais gratter toujours le même morceau de terre, d'année en année, et rester là, je n'aurais jamais pu faire ça tout mon règne : il m’aurait semblé être attaché comme un animal à un pieu (34).

Contrary to the défricheur, the coureur des bois represents a sort of economic nomadism that has no attachment to a particular plot of farmland. Such a relatively boundless movement unsurprisingly attracts aversion; in the novel, the narrator explicitly contrasts the lifestyle of François with that of the agriculturalist Chapdelaine family, C'était l'éternel malentendu des deux races : les pionniers et les sédentaires, les paysans venus de France qui avaient continué sur le sol nouveau leur idéal d'ordre et de paix immobile, et ces autres paysans en qui le vaste pays sauvage avait réveillé un atavisme lointain de vagabondage et d'aventure (53). 
The nomadic pionniers — who in this example signify the coureur des bois — symbolize thus a deplorable unfixity that does not adhere to the colonialist vision of socio-economic order: sedentarizing oneself to a new, yet productive piece, of land; the uncontained nomadism of François is thus positioned as a foil to the desirable constrained migration that is implied by défrichement. Make no mistake, François does seduce Maria- - he is after all her first choice of husband — but the novel ultimately denies her a future with him as he is killed by a winter storm while trying to reach the Chapdelaines for the Christmas réveillon (117). The nomadic vagabondage of the coureur des bois can consequentially be read as a type of rampant migrancy that is incompatible with settler-colonialist and economic exigences.

The third, and final migrant type, is a figure who moves outside the bounds of empire all together; the Franco-American citadin — an immigrant who leaves rural Québec for the industrial centers of New England—can be read as an alternative to the défricheur/coureur des bois struggle over Québec territory. This type is represented by another one of Maria's suitors, Lorenzo Surprenant, a Canadien who emigrates to work in a factory in Massachusetts. Lorenzo effectively represents a migrant potentiality that differs from those of the défricheur and of the coureur des bois: emigration away from the national terroir; while Maria is grieving the loss of François, Lorenzo descends on her and proposes her an opportunity to flee the harshness of the Québec wilds that killed her true love,

Icitte... ce n'est pas une place pour vous, Maria. Le pays est trop dur, et le travail est dur aussi ; on se fait mourir rien que pour gagner son pain. Là-bas, dans les manufactures, fine et forte comme vous êtes, vous auriez vite fait de gagner quasiment autant comme moi ; mais si vous étiez ma femme vous n'auriez pas besoin de travailler. Je gagne assez pour deux, nous nous ferions une belle vie (142). 
With the lure of pecuniary wealth and of respite from the hardships of rural life, Lorenzo proposes a kind of migration that abandons the territorial space targeted by Franco-Canadien colonialist ambitions. Eschewing participation in the mobility/fixity debate over the national soil, the citadin thus represents an alter-migrancy that not only rejects the prerogative to clear the land in the province's boundaries, but also the unbridled movement of the coureur des bois-a wanderer who in the end still remains within the colonial range. Maria's ultimate rejection of Lorenzo thus amounts to a refusal of emigration as a valid migrant practice for Canadiens, deeming it to be other — a very alterity alluded to by Lorenzo's foreign sounding name; the economic privilege associated with his emigration to the States is unsurprisingly ignored because of its extra-coloniality.

Bringing these analyses of Maria's suitors back to my point, my readings demonstrate that the migrant and economic characteristics of these figures complicate established understandings of them as simple expressions of place-based geographical positionalities. The particular migrancy of these figures can be just as telling of their supposed value in the settlercolonialist system; Freitag's statement may therefore easily be reformulated to state that the characters' migrancies are all that is needed to identify their stances in the agriculturalist cause. Let it be clear, this value is not a utilitarian, profit-maximizing, conception of wealth; it is one that is conditional to settler-colonialist ideals of agricultural exploitation. The worth of the défricheur, coureur des bois, and the citadin is determined by the colonialist returns of their migrancy - the ability of their movement to not just generate riches, but specifically riches from the land in the targeted colonial range. My study therefore does not deny the importance of geographical place in the discourses of these novels - settler-colonialism is in the end of the day the system through which land and space are appropriated and repurposed. Nevertheless, Maria 
Chapdelaine serves as a reminder of how this form of colonialism also values mastery over the migratory flows and economic circuits of its agents and subjects. This link between colonialism and migration functions thus as the fulcrum that allows these narratives from the roman de la terre to be read as economic narratives of migration. This all but suggests that one dimension of this migrant novel's historic popularity resides in its appeal to Canadien settler-colonialist conceptions of migration.

What are the implications of this in our present times? After all, Maria Chapdelaine and other rural novels fell out of vogue by the 1940s, which then saw the rise of the roman urbain in Québec literary trends. Nonetheless, the popularity of the same rural themes and motifs continues to persist in other genres and media, even today in the twenty-first century; this is evident by the plethora of Québec cultural productions that seem to play on this settlercolonialist nostalgia - from the lyrics of neo-traditional musicians such as Mes Aïeux and Les Cowboys Fringants, to the adaptations of the roman de la terre in film and television, one example being the Radio-Canada televised series Les Pays d'en Haut (2016) that was inspired by Claude Henri Grignon's novella Un homme et son péché (1933).4 This nostalgia remains present as the provincial government of Québec returns its gaze to its rural regions, evoking migration as a possible means to remedy the labor shortage, as well as to aid in the expansion of natural resource extraction under the Plan Nord.5 In light of these new quasi-colonialist schemes, the question of which migrant discourses and narratives are mobilized by hegemonic forces in their service is as pertinent as ever. However, it can no longer uniquely be the question of how those with power wish for their relationship with migration and the land be depicted; we must also 
interrogate other imaginaries of those integrated and exploited in the province's colonial and migratory circuits, and who all do speak of the land they now share together - the working class, immigrants from across the world, and especially the Indigenous Peoples whose lands are the target.

\section{Works Cited}

Archambault, Sylvain. Les Pays d'En Haut. 2016.

Carrière, Marie J., and Catherine Khordoc, editors. Migrance comparée: les littératures du Canada et du Québec / Comparing migration : the literatures of Canada and Québec. Peter Lang, 2008.

Chapman, Rosemary. Siting the Quebec Novel: The Representation of Space in Francophone Writing in Quebec. Peter Lang AG, Internationaler Verlag der Wissenschaften, 2000.

Desbiens, Caroline. Power from the North: Territory, Identity, and the Culture of Hydroelectricity in Quebec. UBC Press, 2013.

Deschamps, Nicole. “Avant-Propos.” Maria Chapdelaine, by Louis Hémon, Les Éditions du Boréal, 1988.

Freitag, Florian. The Farm Novel in North America: Genre and Nation in the United States, English Canada, and French Canada, 1845-1945. Camden House, 2013.

Grignon, Claude-Henri. Un homme et son péché: les belles histoires des pays d'en haut. 10/10, 1977.

Hamelin, Jean, editor. Histoire Du Québec. France-Amérique, 1978.

Hémon, Louis. Maria Chapdelaine. Les Éditions du Boréal, 1988. 
Memmi, Albert. Portrait Du Colonisé, Précédé de Portrait Du Colonisateur et d'une Préface de Jean Paul Sartre. Gallimard, 1985.

Mirabeau, Victor Riqueti, and Thomas Hale. L'ami des hommes, ou Traité de la population. Volume 1,Partie 3. 1756. gallica.bnf.fr, https://gallica.bnf.fr/ark:/12148/bpt6k1041849k. Rangarajan, Sudarsan. “"The Roman d'Aventures' as a Subgenre in Maria Chapdelaine.” The French Review, vol. 83, no. 4, 2010, p. 740.

Scholl, Dorothee. "French-Canadian Colonial Literature under the Union Jack." History of Literature in Canada, edited by Reingard M. Nischik, Boydell \& Brewer, Camden House, 2008.

Alvin Y. Chuan is a $\mathrm{PhD}$ candidate in the University of Southern California's Comparative Studies in Literature and Culture program. Primarily interested in the literature and culture of Québec, his dissertation project - tentatively titled Migrant Ventures: the Poetics of Migration and Capital in Francophone North America-examines tropes of economic power in Québec and Franco-American migration narratives. 